\title{
Ovarian structures and uterine environment are associated with phenotypic and genetic merit for performance in lactating dairy cows
}

\author{
A.M. Fitzgerald ${ }^{\text {a,b }}$, D.P. Ryan ${ }^{b}$, T.R. Carthy ${ }^{a}$, R.D. Evans ${ }^{c}$, D.P. Berry ${ }^{a, *}$ \\ ${ }^{a}$ Animal E' Grassland Research and Innovation Centre, Teagasc, Moorepark, Co., Cork, Ireland \\ ${ }^{\mathrm{b}}$ Reprodoc Ltd., Fermoy, Co., Cork, Ireland \\ ${ }^{\mathrm{c}}$ Irish Cattle Breeding Federation, Bandon, Co., Cork, Ireland
}

\section{A R T I C L E I N F O}

\section{Article history:}

Received 24 March 2014

Received in revised form 25 July 2014

Accepted 29 July 2014

\section{Keywords:}

Ultrasonography

Multiple ovulation

Cyst

CL presence

Performance

\begin{abstract}
A B S T R A C T
The objective of this study was to estimate the association between detailed reproductive phenotypes for cows categorized as divergent for phenotypic and genetic performance. The hypothesis was that higher yielding animals, either phenotypically or genetically, would have compromised ovarian and uterine reproductive performance. Detailed reproductive traits including multiple ovulations, cystic ovarian structures, corpus luteum (CL) presence, and uterine environment were available on 9675 ultrasound records from 8174 dairy lactating cows, calved between 10 and 70 days. Cows were categorized, within parity, into low, average, or high for each of the performance traits. There was a greater likelihood of multiple ovulations in cows with greater phenotypic yields (odds ratio: 1.53-1.81) and greater genetic merit for yield (odds ratio: 1.31-1.59) relative to lower performing contemporaries. After adjustment for genetic merit, a similar trend of increased odds (odds ratio: 1.29-1.87) of multiple ovulations in higher yielding cows was observed compared with the lowest yielding category. There was no association between either phenotypic milk composition or genetic merit for milk composition with the likelihood of multiple ovulations. The likelihood of cystic ovarian structures was highest in cows with greatest phenotypic milk yields (odds ratio: 2.75-3.24), greater genetic merit for milk yield (odds ratio: 1.30-1.51), and even after adjustment for genetic merit there was a greater likelihood of cystic ovarian structures in cows with the highest milk yields (odds ratio: 2.712.95), compared with cows in the lowest category for each of the milk traits. Cows with average phenotypic milk yields were more likely to have a CL, compared with the lowest yielding category (odds ratio: 1.20-1.23), and these associations remained after adjustment for genetic merit of the trait. The likelihood of CL presence was highest in cows with the lowest genetic merit for milk. Lower fat:protein ratio was associated with an increased likelihood of CL presence compared with cows with greater fat:protein ratio and cows with the highest phenotypic milk composition were more likely to have a CL compared with cows in the lowest composition category. Genetic predisposition to higher somatic cell score was associated with a reduced risk of multiple ovulations (odds ratio: $0.69 ; 95 \% \mathrm{CI}$ : $0.55-0.87$ ) but an increased likelihood of CL presence (odds ratio: 2.66 ; 95\% CI: 2.09-3.37) and poorer uterine health score (odds ratio: 1.36; 95\% CI: 1.20-1.55). There was a lower likelihood of multiple ovulations, cystic ovarian structures, and poorer uterine health and an increased likelihood of CL presence in cows with superior genetic merit for reproductive performance and survival.
\end{abstract}

(c) 2014 Elsevier Inc. All rights reserved.

\footnotetext{
* Corresponding author. Tel.: +35325 42386; fax: +3532542340.

E-mail address: Donagh.berry@teagasc.ie (D.P. Berry).
} 


\section{Introduction}

Dairy cow breeding goals in the early 21st century were broadened to include functional traits like reproductive performance [1]. Many of these breeding goals include aggregate reproductive phenotypes such as calving interval or days open [2]. Such reproductive phenotypes are an accumulation of several underlying, more detailed, reproductive characteristics such as the ability of the animal to return to estrus post-calving concurrent with prompt uterine involution, the ability to express estrus, as well as the ability to conceive and maintain a pregnancy [2]. Although the existence of antagonistic associations between selection for milk production and traditional reproductive traits is already well established [2], there is limited knowledge on the association between animals divergent for genetic merit for milk production and detailed reproductive traits such as follicular dynamics and uterine environment $[3,4]$. Moreover, there is a paucity of information on ovarian structures and uterine environment among animals divergent for genetic merit for aggregate reproductive phenotypes such as calving interval or survival.

Therefore, the objective of the present study was to associate both phenotypic and genetic merit for milk production traits with detailed reproductive phenotypes including multiple ovulations, cystic ovarian structures, corpus luteum presence ( $C L$ presence), and uterine environment and also to quantify the difference in such detailed reproductive phenotypes among animals differing in genetic merit for calving interval, survival, and somatic cell score. The hypothesis was that higher yielding animals, either phenotypically or genetically, would have compromised ovarian and uterine reproductive performance. Results from the present study will be particularly useful in elucidating the impact of selection for milk production on ovarian structures and uterine environment and also determining if selection for aggregate reproductive phenotypes like calving interval is effective in improving all aspects of detailed reproductive performance.

\section{Materials and methods}

\subsection{Ultrasound scans}

Data were available from the Irish Cattle Breeding Federation (ICBF) database on 65,030 transrectal ultrasound observations of the reproductive tract from 41,582 dairy cows in 828 Irish dairy between March 2008 and October 2012. All ultrasonographic measurements were performed by a single company (Reprodoc Ltd., Fermoy, Co. Cork, Ireland; http://www.cowsdna.com). Ultrasonography was performed transrectally using a real-time $\beta$-mode ultrasound scanner with a $5-\mathrm{MHz}$ transducer. Size and echogenicity of ovarian follicles, corpora lutea, uterine tone, and uterine luminal fluids were interpreted, and a classification was assigned based on these combined measures. In the present study, only ultrasound examinations from nonpregnant cows calved between 10 and 70 days were retained.
Detailed reproductive phenotypes were generated from the ultrasound examination and are described in detail by Fitzgerald et al. [5] and Carthy et al. [6]. Phenotypes generated included multiple ovulations, cystic ovarian structures, CL presence, and uterine score. Briefly, multiple ovulations were described in cyclic cows by the presence of two or more corpora on the ovary, indicating the ovulation of two or more follicles in the previous cycle. Cystic ovarian structures were described in nonpregnant cows by the presence of a large fluid-filled structure $(>25 \mathrm{~mm}$ in diameter) on the ovary. A cystic ovarian structure was diagnosed when the CL was $<5 \mathrm{~mm}$ in diameter or when the $\mathrm{CL}$ was absent. $\mathrm{CL}$ presence was described by the identification of a CL on the ovary in the presence of follicles not exceeding $25 \mathrm{~mm}$ in diameter. A CL could be determined during the metestrous, dioestrous, and proestrous stages of the bovine estrous cycle. Multiple ovulations, cystic ovarian structures, and CL presence were coded as binary traits for analysis. Uterine score was described in nonpregnant cows by an assessment of the level of luminal fluid and tone in the uterine horns [6,7]. Four uterine health scores were derived: (1) poor uterine tone with inflammation and more than $60 \mathrm{~mm}$ of luminal fluids; (2) poor uterine tone with 5 to $60 \mathrm{~mm}$ of luminal fluids; (3) normal uterine tone with 2 to $5 \mathrm{~mm}$ of luminal fluids; and (4) normal uterine tone with less than $2 \mathrm{~mm}$ luminal fluids (Fig. 1).

\subsection{Cow and herd characteristics}

Breed composition of the cows were available from the ICBF database; only cows with $\geq 75 \%$ of breed fraction known were retained and consisted of only dairy herds. The majority of the dairy cows in Ireland were HolsteinFriesian, and $96 \%$ of the cows in the present study were Holstein-Friesian. Typically, dairy herds in Ireland are seasonal calving; in the present study, $61 \%$ of cows calved between February and May, 9.50\% calved between June and September, and $29.50 \%$ calved between October and January. The average herd size was 89 . Standard practice for dairy cows in Ireland is to house animals during the winter months with animals being turned out to pasture in the spring.

\subsection{Phenotypic and genetic milk production}

Individual cow test-day records for milk, fat, and protein yield were available from the ICBF database. A smoothing spline with six knot points at 20,70,120, 170, 220, and 270 days post-calving was fitted to each cow's individual test-day record using ASReml [8]. Predicted milk, fat, and protein yield on the day of ultrasonography were deduced by interpolation and extrapolation from the fitted splines; total solids yield was calculated as the sum of fat and protein yield. The predicted yield traits were used to determine milk fat and protein concentration as well as the fat-to-protein ratio. Fat-to-protein ratio is often cited as an indicator of energy balance [9], where a high ratio value is proposed to signify a greater negative energy balance in the cow. 

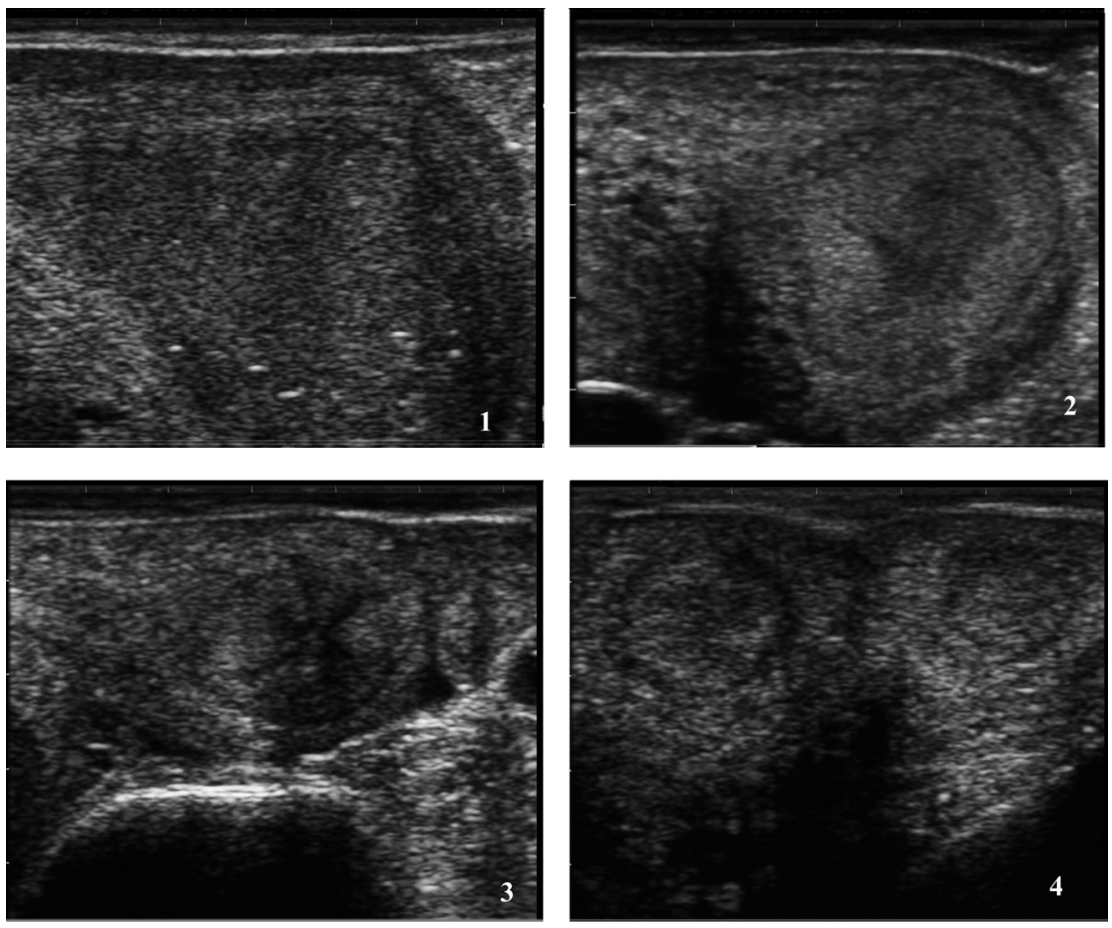

Fig. 1. Representation of uterine health scores: (1) poor uterine tone with more than $60 \mathrm{~mm}$ of luminal fluids, (2) poor uterine tone with 5 to 60 mm of luminal fluids, (3) normal uterine tone with 2 to $5 \mathrm{~mm}$ of luminal fluids, and (4) normal uterine tone with less than $2 \mathrm{~mm}$ luminal fluids.

Predicted transmitting abilities (PTAs) are the official measure of genetic merit for both dairy and beef animals in Ireland and are defined as the average genetic value for a given trait that an animal transmits to its offspring. Individual cow PTAs for 305-day milk yield, fat yield and concentration, and protein yield and concentration and somatic cell score (SCS; natural logarithm of somatic cell count) from the December 2013 national genetic evaluation were available from the ICBF. Genetic evaluations for the milk production and SCS traits are undertaken using a series of multibreed univariate animal repeatability linear models. Total solids yield and concentration were calculated from the sum of PTAs for fat and protein yield and the sum of PTAs for fat and protein concentration, respectively. Individual cow PTA for calving interval and survival were also available from the December 2013 Irish national genetic evaluation. Genetic merit for calving interval and survival is estimated from a multitrait multibreed animal model genetic evaluation of both traits for the first five parities; also included in the multitrait genetic evaluation is calving to first service interval, number of services, (predicted) lifespan, and 305-day milk yield.

\subsection{Data edits}

Daily milk yield, fat yield and concentration, protein yield and concentration, total solids yield and concentration, and fat-to-protein ratio were standardized separately, within parity groups (i.e., 1, 2, 3, 4, and 5+), and categorized as $>0.5$ standard deviation (SD) below the mean (i.e., low), $\pm 0.5 \mathrm{SD}$ from the mean (i.e., medium) and $>0.5 \mathrm{SD}$ above the mean (i.e., high).
Cows were also categorized into three groups of equal size (i.e., low, medium, and high) based on PTAs for milk yield, fat yield and concentration, protein yield and concentration, total solids yield and concentration, as well as SCS, calving interval, and survival. Contemporary group of herdyear-season of calving was defined as described in detail by Berry and Evans [10]. Briefly, animals were grouped together, within herd, that calved in close proximity. Initially calving dates differing by a predefined number of days (in this study 10 days was chosen) were placed in separate contemporary groups. Subsequently, if the number of records within any contemporary group was less than a predefined number (10 was chosen in the present study), they were merged with a contemporary group adjacent in time if the start date and end date of the adjacent contemporary groups was less than a specified number (in this study 182 days was chosen as the threshold). Only contemporary groups with at least five records were retained. Parity records $\geq 5$ were combined into one parity group (i.e., parity 5+). Following edits, 9675 ultrasound records from 8174 lactating cows in 307 commercial dairy herds remained.

\subsection{Statistical analyses}

Factors associated with the logit of the probability of the existence of multiple ovulations, cystic ovarian structures, or CL presence at the time of ultrasonography were quantified separately using generalized estimating equations in ASReml [8] assuming a binomial error distribution. Factors associated with an inferior uterine health score were quantified using ordinal regression in ASReml [8] assuming a multinomial error distribution of the data. 
Fixed effects considered for inclusion in all models were parity, days in milk (included as a linear and quadratic covariate), year, and month of scan. Both cow and contemporary group were included in the models as random effects. In a series of subsequent analyses, each phenotypic milk production variable was included separately in the model as a fixed effect with three classes (i.e., low, average, high). Associations between genetic merit for milk, fat, protein, total solids, SCS, calving interval and survival with multiple ovulations, cystic ovarian structures, CL presence or uterine score on the day of the scan, were also quantified individually. In a final series of analyses the relationship between the phenotypic milk production traits with the detailed fertility traits was quantified using a multiple regression model which also included genetic merit for the milk production trait under investigation; in this instance genetic merit was included in the model as a continuous covariate.

Predicted probability estimates for multiple ovulations, cystic ovarian structures and CL presence in cows of different phenotypic milk production and different genetic merit for milk production and reproductive performance were calculated based on a reference animal. The reference animal was a second parity cow, averaged across all years and months of scanning and 70 days calved.

\section{Results}

\subsection{Multiple ovulations}

The mean prevalence of multiple ovulations was 7.04\%. The likelihood of multiple ovulations increased consistently with increasing phenotypic milk, fat, protein and total solids yield but no association with fat:protein ratio was detected (Table 1). Cows in the highest yielding category were 1.53 to 1.81 times more likely to have multiple ovulations compared with cows in the lowest production group for each of the four yield traits investigated. This manifested itself as a predicted probability of multiple ovulations in the highest yield group of $7.71 \%$ to $8.98 \%$ with a predicted probability of $1.91 \%$ to $4.71 \%$ for multiple ovulations in the lowest yielding group (i.e., an average difference of $1.03 \%$ units between highest and lowest yielding categories).

Even after adjustment for the genetic potential of the milk trait under investigation, the highest yielding cows were at a greater risk of multiple ovulations, although not always significantly different from the lowest yielding category (Table 1). There was no association between phenotypic milk composition and the likelihood of multiple ovulations, with or without adjustment for differences in genetic merit (Table 2).

Multiple ovulations were 1.21 to 1.59 more likely in cows with the highest genetic merit for each of the yield traits compared with the lowest genetic merit group for the respective traits, resulting in a predicted probability of between $0.39 \%$ and $1.08 \%$ units of a difference between the category of cows with greatest and worse genetic merit for the milk production traits. There was no association between multiple ovulations and genetic merit for milk composition (Table 3).

The likelihood of multiple ovulations was lowest in cows genetically predisposed to worse (i.e., higher) SCS (Table 3). Relative to cows with the poorest genetic merit for calving interval or survival, cows of superior genetic merit for calving interval (i.e., shorter calving intervals) or survival (i.e., greatest survival) had a reduced likelihood of multiple ovulations (Table 4). The predicted probability of multiple ovulations was $0.51 \%$ and $0.57 \%$ units lower in cows in the elite genetic merit group for calving interval and survival compared with cows in the respective lowest genetic merit category (Table 4).

Table 1

Odds ratio (95\% confidence interval in parenthesis) of multiple ovulations, cystic ovarian structures, and CL presence for animals in medium and high categories of phenotypic milk yield, fat yield, protein yield total solid yield, and fat:protein relative to the lowest category (i.e., OR = 1 ).

\begin{tabular}{|c|c|c|c|c|c|c|}
\hline \multirow[t]{2}{*}{ Trait } & \multicolumn{2}{|c|}{ Multiple ovulations } & \multicolumn{2}{|c|}{ Cystic ovarian structures } & \multicolumn{2}{|l|}{ CL presence } \\
\hline & Phenotypic & Adjusted $^{\mathrm{a}}$ & Phenotypic & Adjusted $^{\mathrm{a}}$ & Phenotypic & Adjusted $^{\mathrm{a}}$ \\
\hline \multicolumn{7}{|c|}{ Milk yield (kg) } \\
\hline P value & $<0.005$ & 0.06 & $<0.001$ & $<0.005$ & 0.06 & 0.06 \\
\hline Medium & $1.34(1.07-1.68)$ & $1.23(0.97-1.56)$ & $2.42(1.49-3.93)$ & $2.24(1.36-3.70)$ & $1.03(0.84-1.28)$ & $1.29(1.04-1.61)$ \\
\hline High & $1.53(1.20-1.96)$ & $1.29(0.97-1.72)$ & $3.24(1.98-5.33)$ & $2.78(1.60-4.83)$ & $0.82(0.65-1.03)$ & $1.28(0.99-1.67)$ \\
\hline \multicolumn{7}{|c|}{ Fat yield (kg) } \\
\hline P value & $<0.001$ & $<0.05$ & $<0.001$ & $<0.005$ & $<0.05$ & $<0.05$ \\
\hline Medium & $1.29(1.03-1.61)$ & $1.31(1.04-1.67)$ & $2.11(1.35-3.32)$ & $2.18(1.38-3.46)$ & $1.23(1.00-1.52)$ & $1.36(1.10-1.69)$ \\
\hline High & $1.81(1.41-2.31)$ & $1.87(1.43-2.45)$ & $2.75(1.71-4.42)$ & $2.74(1.64-4.57)$ & $0.93(0.74-1.18)$ & $1.14(0.88-1.47)$ \\
\hline \multicolumn{7}{|c|}{ Protein yield $(\mathrm{kg})$} \\
\hline$P$ value & $<0.001$ & $<0.001$ & $<0.001$ & $<0.001$ & 0.18 & $<0.001$ \\
\hline Medium & $1.18(0.94-1.48)$ & $1.15(0.90-1.45)$ & $2.56(1.60-4.14)$ & $2.45(1.51-3.99)$ & $1.22(0.99-1.50)$ & $1.45(1.17-1.81)$ \\
\hline High & $1.65(1.29-2.09)$ & $1.54(1.18-2.03)$ & $2.99(1.82-4.91)$ & $2.71(1.58-4.65)$ & $1.12(0.89-1.42)$ & $1.58(1.22-2.05)$ \\
\hline \multicolumn{7}{|c|}{ Total solids yield (kg) } \\
\hline P value & $<0.001$ & $<0.05$ & $<0.001$ & $<0.0001$ & $<0.05$ & $<0.05$ \\
\hline Medium & $1.37(1.09-1.72)$ & $1.35(1.07-1.71)$ & $1.69(1.07-2.67)$ & $1.70(1.07-2.71)$ & $1.20(0.97-1.49)$ & $1.38(1.10-1.72)$ \\
\hline High & $1.69(1.31-2.16)$ & $1.64(1.25-2.16)$ & $2.93(1.85-4.64)$ & $2.95(1.79-4.88)$ & $0.89(0.71-1.13)$ & $1.16(0.89-1.51)$ \\
\hline \multicolumn{7}{|c|}{ Fat:protein ratio } \\
\hline$P$ value & 0.74 & & 0.59 & & $<0.05$ & \\
\hline Medium & $1.06(0.86-1.31)$ & & $1.17(0.80-1.71)$ & & $0.77(0.62-0.95)$ & \\
\hline High & $1.10(0.86-1.41)$ & & $1.24(0.80-1.92)$ & & $0.87(0.68-1.10)$ & \\
\hline
\end{tabular}

\footnotetext{
a Phenotypic associations after adjustment for differences in genetic merit for the trait.
} 
Table 2

Odds ratio (95\% confidence interval in parenthesis) of multiple ovulations, cystic ovarian structures, and CL presence for animals in medium and high categories fat composition, protein composition total solid composition relative to the lowest category (i.e., OR $=1$ ).

\begin{tabular}{|c|c|c|c|c|c|c|}
\hline \multirow[t]{2}{*}{ Trait (\%) } & \multicolumn{2}{|c|}{ Multiple ovulations } & \multicolumn{2}{|c|}{ Cystic ovarian structures } & \multicolumn{2}{|l|}{ CL presence } \\
\hline & Phenotypic & Adjusted $^{\mathrm{a}}$ & Phenotypic & Adjusted $^{\mathrm{a}}$ & Phenotypic & Adjusted $^{\mathrm{a}}$ \\
\hline \multicolumn{7}{|l|}{ Fat } \\
\hline P value & 0.89 & 0.46 & 0.64 & $<0.05$ & $<0.05$ & 0.36 \\
\hline Medium & $0.95(0.77-1.17)$ & $1.06(0.85-1.33)$ & $1.13(0.78-1.64)$ & $1.44(0.96-2.14)$ & $1.07(0.88-1.30)$ & $0.97(0.78-1.19)$ \\
\hline High & $0.98(0.77-1.24)$ & $1.19(0.90-1.57)$ & $1.22(0.80-1.86)$ & $1.83(1.14-2.96)$ & $1.36(1.08-1.71)$ & $1.13(0.87-1.47)$ \\
\hline \multicolumn{7}{|l|}{ Protein } \\
\hline$P$ value & 0.64 & 0.59 & $<0.01$ & $<0.005$ & $<0.0001$ & $<0.0001$ \\
\hline Medium & $0.94(0.76-1.16)$ & $0.93(0.76-1.15)$ & $0.92(0.65-1.29)$ & $0.89(0.64-1.27)$ & $1.35(1.11-1.63)$ & $1.38(1.14-1.67)$ \\
\hline High & $0.89(0.71-1.13)$ & $0.89(0.70-1.12)$ & $0.48(0.31-0.76)$ & $0.47(0.30-0.74)$ & $2.00(1.59-2.53)$ & $2.07(1.64-2.61)$ \\
\hline \multicolumn{7}{|l|}{ Total solids } \\
\hline P value & 0.95 & 0.41 & 0.93 & 0.40 & $<0.0001$ & $<0.05$ \\
\hline Medium & $0.98(0.79-1.21)$ & $1.11(0.88-1.39)$ & $1.02(0.71-1.47)$ & $1.25(0.85-1.86)$ & $1.02(0.84-1.25)$ & $0.92(0.74-1.14)$ \\
\hline High & $0.96(0.76-1.21)$ & $1.21(0.91-1.61)$ & $0.95(0.62-1.45)$ & $1.38(0.84-2.24)$ & $1.57(1.25-1.97)$ & $1.27(0.97-1.66)$ \\
\hline
\end{tabular}

a Phenotypic associations after adjustment for differences in genetic merit for the trait.

\subsection{Cystic ovarian structures}

The mean prevalence of cystic ovarian structures was $1.91 \%$ in the present study. The likelihood of cystic ovarian structures increased almost linearly with increasing phenotypic milk yield, fat yield, protein yield and total solids yield, but no association with fat:protein ratio was detected (Table 1). Cows in the greatest yield category were approximately three times (i.e., 2.75-3.24 times) more likely to have cystic ovarian structures at the time of ultrasonography compared with the lowest yielding cows. This manifested itself as a predicted probability of cystic ovarian structures in the highest yielding group of $2.28 \%$ to $6.83 \%$ compared with a predicted probability of $0.71 \%$ to $2.39 \%$ for cystic ovarian structures in the lowest yielding group (i.e., average difference of 5.53\% units between highest and lowest yielding categories). Even after adjustment for differences in the genetic potential of the yield trait under investigation, the association between a greater likelihood of

Table 3

Odds ratio $^{\mathrm{a}}$ (95\% confidence interval in parentheses) for multiple ovulations (MO), cystic ovarian structures (CYST), CL presence (CL), and inferior uterine score (US) for different levels of genetic merit for milk yield, fat, protein, total solids, and somatic cell score (SCS).

\begin{tabular}{|c|c|c|c|c|}
\hline Trait & MO & CYST & $\mathrm{CL}$ & US \\
\hline \multicolumn{5}{|l|}{ Milk yield (kg) } \\
\hline$P$ value & $<0.001$ & 0.12 & $<0.001$ & 0.15 \\
\hline Medium & $1.42(1.13-1.78)$ & $1.28(0.86-1.91)$ & $0.70(0.56-0.87)$ & $1.04(0.93-1.76)$ \\
\hline High & $1.59(1.27-2.00)$ & $1.51(1.06-2.26)$ & $0.50(0.40-0.62)$ & $0.93(0.81-1.06)$ \\
\hline \multicolumn{5}{|l|}{ Fat yield (kg) } \\
\hline$P$ value & 0.22 & 0.16 & $<0.05$ & 0.95 \\
\hline Medium & $1.08(0.87-1.34)$ & $0.90(0.61-1.34)$ & $0.77(0.63-0.94)$ & $1.02(0.90-1.14)$ \\
\hline High & $1.21(0.97-1.51)$ & $1.30(0.89-1.88)$ & $0.79(0.64-0.97)$ & $1.00(0.87-1.15)$ \\
\hline \multicolumn{5}{|c|}{ Protein yield (kg) } \\
\hline$P$ value & $<0.01$ & 0.12 & $<0.001$ & 0.30 \\
\hline Medium & $1.31(1.05-1.63)$ & $1.25(0.84-1.85)$ & $0.76(0.62-0.94)$ & $1.08(0.33-3.58)$ \\
\hline High & $1.39(1.11-1.74)$ & $1.49(1.02-2.17)$ & $0.67(0.54-0.82)$ & $1.00(0.87-1.14)$ \\
\hline \multicolumn{5}{|c|}{ Total solids yield (kg) } \\
\hline$P$ value & $<0.05$ & 0.24 & $<0.001$ & 0.99 \\
\hline Medium & $1.20(0.96-1.49)$ & $1.11(0.76-1.64)$ & $0.72(0.58-0.88)$ & $0.99(0.89-1.12)$ \\
\hline High & $1.31(1.05-1.64)$ & $1.38(0.94-2.01)$ & $0.64(0.51-0.79)$ & $0.99(0.86-1.14)$ \\
\hline \multicolumn{5}{|c|}{ Fat concentration (\%) } \\
\hline$P$ value & 0.06 & $<0.05$ & $<0.005$ & 0.80 \\
\hline Medium & $0.92(0.75-1.14)$ & $0.88(0.62-1.24)$ & $1.14(0.94-1.38)$ & $1.02(0.90-1.14)$ \\
\hline High & $0.76(0.60-0.96)$ & $0.58(0.38-0.88)$ & $1.34(1.07-1.66)$ & $0.98(0.86-1.11)$ \\
\hline \multicolumn{5}{|c|}{ Protein concentration (\%) } \\
\hline P value & 0.06 & 0.15 & $<0.05$ & 0.42 \\
\hline Medium & $0.82(0.67-1.02)$ & $0.77(0.54-1.11)$ & $1.18(0.97-1.43)$ & $0.93(0.83-1.05)$ \\
\hline High & $0.78(0.62-0.98)$ & $0.70(0.47-1.03)$ & $1.50(1.20-1.86)$ & $0.94(0.83-1.06)$ \\
\hline \multicolumn{5}{|c|}{ Total solids concentration (\%) } \\
\hline P value & 0.13 & $<0.05$ & $<0.005$ & 0.34 \\
\hline Medium & $0.85(0.69-1.06)$ & $0.84(0.59-1.19)$ & $1.24(1.02-1.51)$ & $1.02(0.91-1.15)$ \\
\hline High & $0.80(0.64-1.00)$ & $0.58(0.38-0.87)$ & $1.49(1.20-1.85)$ & $0.93(0.27-3.30)$ \\
\hline \multicolumn{5}{|l|}{ SCS } \\
\hline$P$ value & $<0.006$ & 0.05 & $<0.0001$ & $<0.0001$ \\
\hline Medium & $0.79(0.64-1.06)$ & $0.73(0.50-0.99)$ & $1.59(1.30-1.94)$ & $1.14(1.00-1.29)$ \\
\hline High & $0.69(0.55-0.87)$ & $0.62(0.41-0.93)$ & $2.66(2.09-3.37)$ & $1.36(1.20-1.55)$ \\
\hline
\end{tabular}

\footnotetext{
a Referent category (i.e., odds ratio $=1$ ) was low.
} 
Table 4

Predicted probability (95\% confidence intervals in parentheses) and odds ratio for multiple ovulations (MO), cystic ovarian structures (CYST), CL presence $(\mathrm{CL})$, and inferior uterine score (US) for different levels of genetic merit for calving interval and survival.

\begin{tabular}{|c|c|c|c|c|}
\hline \multirow[t]{2}{*}{ Trait } & \multicolumn{2}{|l|}{ Calving interval } & \multicolumn{2}{|l|}{ Survival } \\
\hline & Predicted probability ${ }^{\mathrm{a}} \%$ ) & Odds ratio & Predicted probability ${ }^{\mathrm{b}}(\%)$ & Odds ratio \\
\hline \multicolumn{5}{|l|}{ MO } \\
\hline$P$ value & $<0.01$ & & $<0.005$ & \\
\hline Inferior & 1.70 & 1 & 1.89 & 1 \\
\hline Average & 1.39 & $0.82(0.66-1.01)$ & 1.63 & $0.86(0.69-1.06)$ \\
\hline Superior & 1.19 & $0.69(0.55-0.88)$ & 1.32 & $0.69(0.55-0.87)$ \\
\hline \multicolumn{5}{|l|}{ CYST } \\
\hline$P$ value & $<0.005$ & & $<0.05$ & \\
\hline Inferior & 2.41 & 1 & 2.09 & 1 \\
\hline Average & 2.12 & $0.88(0.61-1.25)$ & 1.43 & $0.68(0.47-0.99)$ \\
\hline Superior & 1.09 & $0.45(0.29-0.69)$ & 1.33 & $0.64(0.43-0.93)$ \\
\hline \multicolumn{5}{|l|}{$\mathrm{CL}$} \\
\hline$P$ value & $<0.001$ & & $<0.001$ & \\
\hline Inferior & 44.41 & 1 & 39.07 & 1 \\
\hline Average & 60.13 & $1.89(1.54-2.31)$ & 51.59 & $1.66(1.37-2.01)$ \\
\hline Superior & 70.46 & $2.99(2.35-3.79)$ & 63.03 & $2.66(2.12-3.33)$ \\
\hline \multicolumn{5}{|l|}{ US } \\
\hline$P$ value & & $<0.005$ & & $<0.001$ \\
\hline Inferior & & 1 & & 1 \\
\hline Average & & $0.87(0.69-0.88)$ & & $0.78(0.69-0.88)$ \\
\hline Superior & & $0.76(0.66-0.86)$ & & $0.76(0.67-0.86)$ \\
\hline
\end{tabular}

${ }^{a}$ Referent animal was a second parity dairy cow, with average estimates for all years and month scanned with average reproductive performance and 70 days calved.

${ }^{\mathrm{b}}$ Referent animal was a second parity dairy cow, with average estimates for all years and month scanned with average survival and 70 days calved.

cystic ovarian structures with greater phenotypic yield persisted (Table 1). The likelihood of cystic ovarian structures was greatest in cows in the lowest protein composition category, even after adjustment for genetic merit for protein composition. The odds of cystic ovarian structures was 2.08 times greater in cows with the lowest protein composition compared with the highest category (Table 2); this resulted in a $1.47 \%$ unit difference in predicted probability between lowest and highest phenotypic protein composition categories. Milk fat composition or total solid composition was not associated with the likelihood of cystic ovarian structures (Table 2).

Cows with a genetic potential for superior reproductive performance (i.e., shorter calving interval) and improved survival were 1.56 to 2.22 times less likely to have cystic ovarian structures compared with cows with inferior reproductive performance and inferior survival (Table 4). This resulted in a $1.32 \%$ and $0.76 \%$ unit reduction in the predicted probability of cystic ovaries for cows in the superior genetic group for calving interval and survival, respectively, compared with cows in the lowest genetic merit categories (Table 4).

\subsection{CL presence}

The mean prevalence of cows that had cycled on the day of the scan was $89.75 \%$, where the median day of ultrasound scan was 48 days. The proportion of cows with a CL present at 10-day intervals post-calving is in Table 5; the proportion increased consistently with days calved. The category of cows with the greatest phenotypic fat yield, total solids yield, and fat:protein ratio had a reduced likelihood of CL presence at the time ultrasonography compared with the lowest respective category (Table 1 ). This was equivalent to a $1.68 \%$ to $4.71 \%$ unit reduction in the predicted probability of $\mathrm{CL}$ presence between the lowest and greatest production cows. Neither phenotypic milk yield nor phenotypic protein yield were associated with CL presence on the day of ultrasonography. After adjustment for differences in genetic merit in the multiple regression model, cows with average fat yield, the highest protein yield, and average total solids yield had a greater likelihood of CL presence on the day of ultrasonography compared with cows in the lowest category for each of the traits (Table 1 ).

Cows with the greatest phenotypic milk fat, protein, and total solid composition were 1.36 to 2.01 times more likely to have a CL on the day of ultrasonography compared with cows of lowest milk composition (Table 2). This was equivalent to a $7.28 \%$ and $16.96 \%$ unit difference in the predicted probability of CL presence between greatest and lowest production categories.

Cows of greater genetic merit for milk, fat, protein, and total solid yield had a reduced likelihood of CL presence at the time of ultrasonography compared with cows of below

Table 5

Proportion of cows with CL presence at different intervals post-calving.

\begin{tabular}{lllllll}
\hline Statistic & Days calved & & & & \\
\cline { 2 - 6 } & $10-20$ days & $21-30$ days & $31-40$ days & $41-50$ days & $51-60$ days & $61-70$ days \\
\hline Number of records & 623 & 1004 & 1491 & 1799 & 2025 & 2147 \\
Proportion of cows with CL & $50.4 \%$ & $82.07 \%$ & $88.2 \%$ & $93.11 \%$ & $96.25 \%$ & $96.88 \%$ \\
\hline
\end{tabular}


average genetic merit for the production traits (Table 3). This meant that the predicted probability of CL presence in cows at the time of ultrasonography was between $5.19 \%$ and $14.60 \%$ units greater in cows with lowest genetic merit compared with cows of greatest genetic merit for milk production. Cows in the highest genetic merit category for fat, protein, and total solid composition were 1.34 to 1.49 times more likely to have a CL on the day of the ultrasound scan compared with the lowest category for each compositional trait.

Cows in the highest SCS category (i.e., worse) genetically were 2.66 times more likely to have a CL on the day of the scan compared with the lowest category of SCS cows (Table 3). Cows in the elite genetic merit group for reproductive performance and survival had a greater likelihood of CL presence on the day of the scan compared with their genetically inferior counterparts (Table 4). The predicted probability of CL presence was between $26.05 \%$ and $23.96 \%$ units greater in cows with superior genetics for calving interval and survival, respectively, compared with the inferior group (Table 4).

\subsection{Uterine health score}

The prevalence of uterine scores 1 to 4 were $1.09 \%$, $12.71 \%, 20.83 \%$, and $65.38 \%$, respectively. No association with uterine health score existed for any of the phenotypic yield traits or milk compositional traits. After adjustment for differences in genetic merit for the milk production trait under investigation, however, cows with greater phenotypic milk yield were less likely to have a compromised uterine score relative to the lowest yielding cows (OR: 0.85; 95\% CI: 0.72-0.99). Genetic merit for milk production was not associated with the likelihood of a compromised uterine score. The likelihood of a poorer uterine health score was greater in cows genetically predisposed to higher SCS (Table 3), inferior reproductive performance, and shorter survival (Table 4).

\section{Discussion}

\subsection{Milk production and detailed reproductive traits}

Previous research in dairy cows has generally reported unfavorable associations between phenotypic and genetic merit for milk production with reproductive efficiency $[3,11,12]$ corroborating results from the present study.

Gümen et al. [10] demonstrated that, in general, the incidence of multiple ovulations is greater in cows in the early postpartum period; unfortunately no information was available in the present study on which ovulation the ultrasound scan related to (i.e., first or consecutive ovulation). Nevertheless, consistent with studies in US dairy cows, a relationship between greater phenotypic milk yield and a greater prevalence of multiple ovulations was observed in the present study. Fricke and Wiltbank [13] documented a multiple ovulation prevalence of $6.90 \%$ in cows producing less than $40 \mathrm{~kg}$ milk and a prevalence of $20.20 \%$ in cows producing more than $40 \mathrm{~kg}$ milk. Similarly, Lopez et al. [14] reported a mean prevalence of multiple ovulations of $2.5 \%$ and $51.60 \%$ for cows producing low and high milk yield, respectively. This compares with a mean prevalence in the present study of $5.34 \%$ and $8.71 \%$ for cows in the lowest and highest milk yield category, respectively. Although a similar trend was observed, milk production in Irish dairy farms is less than in US dairy production systems, which may account for the reduced overall prevalence of multiple ovulations in the present study. Alterations to the hypothalamic-pituitary-gonadal axis in high-producing cows leading to disruption of normal folliculogenesis is a likely reason for the greater prevalence of multiple ovulations in cows with greater milk yield [15]. To our knowledge, no previous study has investigated the relationship between genetic merit for milk production and multiple ovulations. The moderate genetic correlation that exists between multiple ovulations and twin births in cattle [5] indicates that (in)direct selection for multiple ovulations can increase the likelihood of twin births in cattle and vice versa. Milk production [16] and twin birth rate [17] have increased almost consistently in dairy cows annually, and dairy cows bearing twins have greater peak or cumulative milk yield compared to cows with singleton calvings [17-19]. It is therefore not surprising that, from an evolutionary standpoint, cows that exhibit multiple ovulations have greater phenotypic and genetic merit for milk yield, in order to supply sufficient milk to support twins calves. Additionally, in cows, ovulation rate and milk production traits share at least a common genomic region on BTA14 [20], indicating a potentially close genetic and possibly evolutionary association between the two traits.

Cystic ovaries and anestrous are undesirable reproductive phenotypes that cause infertility through ovulation failure. Similar to studies in Dutch [21], Spanish [22], and German [23] dairy herds, cows producing more milk had a greater incidence of cystic ovaries, presumably through alterations to the hypothalamic-pituitary-gonadal axis, particularly failure of the preovulatory LH surge [24,25]. Cystic ovaries have previously been reported to be positively genetically correlated with 305-day milk yield in both Dutch [26] and Canadian Holstein [27] cows. Corroborating these previously reported genetic correlations, albeit not always statistically significant in the present study, there was a greater likelihood of cystic ovaries in cows genetically predisposed to higher milk production and is a likely contributing factor to the known genetic antagonisms between milk production and traditional fertility traits [2]. Sometimes cited as an indicator of energy balance [9], there was no association between the fat:protein ratio and ovarian cystic structures in the present study. Although VanHolder et al. [28] described an association between negative energy balance and development of ovarian cystic structures, no general consensus exists on the relationship between fat:protein ratio and energy balance [29], which may help explain the somewhat unexpected lack of an association between fat:protein ratio and presence of cystic ovaries.

Delayed return to cyclicity postpartum is an undesirable event that has previously been reported to become more prevalent with selection for increased milk yield $[3,30]$. Furthermore, anestrous persists for longer post-calving in cows of superior genetic merit for milk production compared with cows of lower genetic merit for milk production [4,31]. This association is likely due to the known association 
between increased genetic merit for milk production and greater body condition score loss [32,33], which can alter hormonal profiles, particularly LH-pulsatility and prevent ovulation [4,32]. Body condition score at calving is known to be associated with traits related to return-to-estrus postpartum [34,35]. A decline in the likelihood of the presence of a CL at ultrasonography in cows of superior genetic merit for milk production in the present study therefore provides further evidence for greater anestrous in cows selected for high milk production. In a study by Lopez et al. [36], no difference existed in the interval from calving to estrus in cows housed in free-stall barns producing either high or low phenotypic milk yield. Discrepancies between studies may be due to a multitude of factors including management differences (e.g., housing type), interval from days calved to ultrasonography, and also past breeding programs. Ireland operates a seasonal calving production system, so, therefore, germplasm associated with rapid return to estrus postpartum has historically been favored. Ultrasonography was only performed in cows more than 50 days calved by Lopez et al. [36], whereas in the present study ultrasonography was performed in any cow presented for examination from 10 days calved. Limiting the dataset to cows calved 50 to 70 did not impact on the trend of the associations between milk production and CL presence although statistical significance in the latter analysis did not always exist; this may be due to Type II errors because of the smaller dataset.

Fleischer et al. [23] failed to detect a relationship between milk yield and metritis, confirming results in the present study related to uterine score. Inferior uterine environment most likely develops at calving and is known to be associated with dystocia [6], potentially leading to retained fetal membranes. Even when limited to cows calved 20 to 40 days, no association between phenotypic yield and uterine score was detected.

Associated studies to date, however, on multiple ovulations, cystic ovaries, and anestrus have only investigated the presence of either a phenotypic or a genetic association with milk yield, and it is not clear if the detected phenotypic associations are simply manifestations of underlying genetic correlations or due to environmental associations (i.e., management), or both. Elucidating the underlying contributing factors was undertaken in the present study by quantifying the association between phenotypic milk production with detailed fertility phenotypes after adjustment for differences in genetic merit for the milk production variable under investigation. The results demonstrated that, in general, cows with greater phenotypic milk production had an increased likelihood of multiple ovulations and cystic ovarian structures, irrespective of genetic merit. Thus, farm management practices can affect the prevalence of these detailed reproductive phenotypes independent of the genetic merit of the cow for yield. Moreover, the partial effect of both phenotypic and genetic merit for milk production in the multiple regression model suggest that both cow attributes are additive.

Farm management practices such as nutrition and body condition score (BCS) have been implicated in multiple ovulations, cystic ovaries, anestrous, and uterine environment. In sheep, for example, the practice of "flushing" involves the feeding of a higher plane of nutrition directly before and during the breeding season with the objective of increasing the incidence of multiple ovulations and accordingly multiple births [37]. Furthermore, López-Gatius et al. [22] demonstrated that the risk of cystic ovaries increased by 8.4 times with a one-unit increase in BCS, while loss in body condition was related to anestrus [38,39]. Prepartum supplementation with vitamin $\mathrm{E}$ is associated with a decreased risk of retained fetal membranes [40], and therefore may be useful to maintain desirable uterine conditions postpartum.

\subsection{Genetic merit for udder health}

Mastitis has been shown to be associated with longer intervals to first service, increased days open, and more serves per conception [41] and is also known to be associated with fetal abortions [42]. In the present study, cows genetically predisposed to increased SCS had a reduced risk of multiple ovulations and increased likelihood of a $C L$ being present at examination. A positive genetic correlation between retained fetal membranes and mastitis has previously been documented [43], and this is of biological importance because retained fetal membranes can give rise to undesirable uterine environments [44]. In addition, retention of fetal membranes postpartum has been shown to be associated within an increased risk of mastitis compared with cows that expelled fetal membranes [45]. The association between genetic merit for SCS and uterine environment in the current study therefore demonstrates an association between sub-clinical mastitis and reproductive performance in commercial dairy cows through its negative effect on sustaining a healthy uterus necessary for the establishment of pregnancy.

\subsection{Predicted transmitting ability for both reproductive performance and survival}

Reproductive performance and cow survival are both highly complex traits influenced, and contributed to, by many underlying factors. Genetic evaluations for reproductive performance in Ireland is based on calving interval while the phenotype used in the genetic evaluation of survival is the binary trait of whether or not a cow appeared in the subsequent lactation [46]. What is not clear is whether such breeding strategies, which are similar to those operated in most national breeding programs (e.g., selection on days open or a derivative of such), are actually improving all aspects of reproductive performance. Results from the present study show that selection for improved genetic merit for survival or reproductive performance (i.e., calving interval), in this population at least, is, on average, reducing the incidence of multiple ovulations, cystic ovarian structures, and anestrus while also improving uterine health. Selection of cows with superior reproductive performance and survival can therefore help reduce veterinarian and treatment costs thus benefitting the producer economically. Moreover, it also suggests that these detailed reproductive traits could possibly be useful in multi-trait genetic evaluations to generate accurate estimated breeding values for traditional reproductive traits. 
Multiple ovulations can impair subsequent reproductive efficiency through its genetic correlation with twinning rate [5], which in turn can reduce subsequent conception rates and increase calving interval $[47,48]$, thereby agreeing with the associations observed in the present study. Cystic ovaries cause temporary infertility and impair reproductive efficiency due to the persistence of cysts for up to 10 days [49], thereby extending the calving interval [50]. Additionally, prompt post-partum uterine involution, return to cyclicity and clearance of uterine contaminants are all necessary for the establishment of pregnancy. Corroborating this, cows with superior reproductive performance and survival were more likely to have a CL present on the day of ultrasonography. Only cows with regular estrous cycles and expression of estrus will be inseminated. Therefore, it is logical that calving interval is extended and survival is reduced in cows that fail to exhibit normal estrous activity substantiating the associations observed in the present study.

Uterine contamination is normal in cows directly postcalving and can recover spontaneously [51]. In some instances, uterine contamination can persist and lead to the development of clinical conditions such as endometritis and metritis, which can have unfavourable repercussions on reproductive efficiency [52,53]. In the current study, cows of superior genetic merit for reproductive performance and survival had more desirable uterine environments, dictated by less luminal fluids and normal uterine tone. This preferred uterine environment provides the necessary conditions for conception and maintenance of pregnancy, thereby helping to maintain a compact calving pattern and increasing survival compared with cows with compromised uterine environment.

The present study confirms a role for both phenotypic and genotypic milk production on the likelihood of multiple ovulations, cystic ovaries and anestrous. In addition, selection for cows of superior reproductive performance and survival through breeding goals such as the economic breeding index (EBI) in Ireland, is expected to reduce the likelihood of multiple ovulations and cystic ovaries, increase the likelihood of CL presence and improve uterine environment in early post-partum cows.

\section{References}

[1] Miglior F, Muir BL, van Doormaal BJ. Selection indices in Holstein cattle of various countries. J Dairy Sci 2005;88:1255-63.

[2] Berry DP, Wall E, Pryce JP. Genetics and genomics of reproductive performance in dairy and beef cattle. Animal 2014;8:105-21.

[3] Royal MD, Flint AP, Woolliams JA. Genetic and phenotypic relationships among endocrine and traditional fertility traits and production traits in Holstein-Friesian dairy cows. J Dairy Sci 2002; 85:95-967.

[4] Gutierrez CG, Gong JG, Bramley TA, Webb R. Selection on predicted breeding value for milk production delays ovulation independently of changes in follicular development, milk production and body weight. Anim Reprod Sci 2006;95:193-205.

[5] Fitzgerald AM, Berry DP, Carthy T, Cromie AR, Ryan DP. Risk factors associated with multiple ovulation and twin birth rate in Irish dairy and beef cattle. J Anim Sci 2014;92:966-73.

[6] Carthy TR, Fitzgerald AM, Berry DP, McParland S, Williams EJ, Butler ST, et al. Risk factors associated with detailed reproductive phenotypes in dairy and beef cows. Animal 2014;8:695-703.

[7] Mee JF, Buckley F, Ryan D, Dillon P. Pre-breeding ovaro-uterine ultrasonography and its relationship with first service pregnancy rate in seasonal-calving dairy herds. Reprod Domest Anim 2009;44: $331-7$.

[8] Gilmour AR, Cullis BR, Welham SJ, Tompson R. ASREML reference manual, New South Wales Agriculture. Orange, Australia: Orange Agricultural Institute; 2009.

[9] Toni F, Vincenti L, Grigoletto L, Ricci A, Schukken YH. Early lactation ratio of fat and protein percentage in milk is associated with health, milk production, and survival. J Dairy Sci 2011;94:1772-83.

[10] Gümen A, Rastani RR, Grummer RR, Wiltbank MC. Reduced dry periods and varying prepartum diets alter postpartum ovulations and reproductive measures. J Dairy Sci 2005;88:2401-11.

[11] Berry DP, Evans RD. Genetics of reproductive performance in seasonal calving beef cows and its association with performance traits. J Anim Sci 2014;92:1412-22.

[12] Pöso J, Mäntysaari ESA. Genetic relationships between reproductive disorders, operational days open and milk yield. Livest Prod Sci 1996;46:41-8.

[13] Frick PM, Wiltbank MC. Effect of milk production on the incidence of double ovulation in dairy cows. Theriogenology 1999; 52:1133-43.

[14] Lopez H, Caraviello DZ, Satter LD, Fricke PM, Wiltbank MC. Relationship between level of milk production and multiple ovulations in lactating dairy cows. J Dairy Sci 2005;88:2783-93.

[15] Wiltbank MC, Fricke PM, Sangsritavong S, Sartori R, Ginther OJ. Mechanisms that prevent and produce double ovulations in cattle. J Dairy Sci 2000;83:2998-3007.

[16] Evans RD, Dillon P, Buckley F, Berry DP, Wallace M, Ducrocq V, et al. Trends in milk production, calving rate and survival of cows in 14 Irish dairy herds as a result of the introgression of Holstein-Friesian genes. Anim Sci 2006;82:423-33.

[17] Kinsel ML, Marsh WE, Ruegg PL, Etherington WG. Risk factors for twinning in dairy cows. J Dairy Sci 1998;81:989-93.

[18] Nielan M, Schukken YH, Scholl DT, Wilbrink HJ, Brand A. Twinning in dairy cattle: a study of risk factors and effects. Theriogenology 1989;32:845-62.

[19] Hossein-Zadeh NG. The effect of twinning on milk yield, dystocia, calf birth weight and open days in Holstein dairy cows of Iran. J Anim Physiol Anim Nutr (Berl.) 2010;94:780-7.

[20] Wibowo TA, Gaskins CT, Newberry RC, Thorgaard GH, Michal JJ, Jiang Z. Genome assembly anchored QTL map of bovine chromosome 14. Int J Biol Sci 2008;4:406-14.

[21] Heuer C, Schukken YH, Donnelaar P. Postpartum body condition score and results from the first day milk as predictor of disease, fertility, yield and culling in commercial dairy herds. J Dairy Sci 1999;82:295-304.

[22] López-Gatius F, Santolaria P, Yániz J, French M, López-Béjar M. Risk factors for postpartum ovarian cysts and their spontaneous recovery or persistence in lactating dairy cows. Theriogenology 2002;58: 1623-32.

[23] Fleischer P, Metzner M, Beyerbach M, Hoedemaker M, Klee W. The relationship between milk yield and the incidence of some diseases in dairy cows. J Dairy Sci 2001;84:2025-35.

[24] Silva WJ, Hatler TB, Nugent AM, Laranja da Fonseca LF. Ovarian follicular cysts in dairy cows: an abnormality in folliculogenesis. Domest Anim Endocrinol 2002;23:167-77.

[25] Todoroki J, Kaneko H. Formation of follicular cysts in cattle and therapeutic effects of controlled internal drug release. J Reprod Dev 2006;52:1-11.

[26] Hooijer GA, Lubbers RB, Ducri BJ, van Arendonk JA, Kaallansbergen LM, van der Lende T. Genetic parameters for cystic ovarian disease in Dutch black and white dairy cattle. J Dairy Sci 2001;84:286-91.

[27] Van Dorp TE, Dekkers JC, Martin SW, Noordhuizen JP. Genetic parameters of health disorders, and relationships with 305-day milk yield and conformation traits of registered Holstein Cows. J Dairy Sci 1998;81:2264-70.

[28] VanHolder T, Opsomer G, De Kruif A. Aetiology and pathogenesis of cystic ovarian follicles in dairy cattle: a review. Reprod Nutr Dev 2006;46:105-19.

[29] McParland S, Banos G, Wall E, Coffey P, Soyeurt H, Veerkamp RF, et al. The use of mid-infrared spectrometry to predict energy status of Holstein cows. J Dairy Sci 2011;94:3651-61.

[30] Veerkamp RF, Oldenbroek JK, van der Gaast HJ, van der Werf JH. Genetic correlation between days until start of luteal activity and milk yield, energy balance, and live weights. J Dairy Sci 2000;86: 577-83.

[31] Bamber RL, Shook GE, Wiltbank MC, Santos JEP, Fricke PM. Genetic parameters for anovulation and pregnancy loss in dairy cattle. J Dairy Sci 2009;92:5739-53. 
[32] Butler WR. Energy balance relationships with follicular development, ovulation and fertility in postpartum dairy cows. Livest Prod Sci 2003;83:211-8.

[33] Berry DP, Buckley F, Dillon O, Evans RD, Rath M, Veerkamp RF. Genetic relationships among body condition score, body weight, milk yield and fertility in dairy cows. J Dairy Sci 2003;86:2193-204.

[34] Beam WR. Nutritional interactions with reproductive performance in dairy cattle. Anim Reprod Sci 2000;60-61:449-57.

[35] Roche JR, Macdonald KA, Burke CR, Lee JM, Berry DP. Associations among body condition score, body weight, and reproductive performance in seasonal-calving dairy cattle. J Dairy Sci 2007;90:376-91.

[36] Lopez H, Satter LD, Wiltbank MC. Relationship between level of milk production and estrous behaviour of lactating dairy cows. Anim Reprod Sci 2004;81:209-23.

[37] Gordon IR, editor. Reproductive technologies in farm animals. Chapter 8. Controlling multiple births and litter size. Wallingford Oxfordshire: CABI Publishing, CAB International; 2004.p. 195-214.

[38] Beam SW, Butler WR. Energy balance and ovarian follicle development prior to the first ovulation postpartum in dairy cows receiving three levels of dietary fat. Biol Reprod 1997;56:133-42.

[39] Wiltbank MC, Gümen A, Sartori R. Physiological classification of anovulatory conditions in cattle. Theriogenology 2002:57:21-52.

[40] Bourne N, Laven R, Wathes DC, Martinez T, McGowan M. A metaanalysis of the effects of vitamin E supplementation on the incidence of retained foetal membranes in dairy cows. Theriogenology 2007;67:494-501.

[41] Schrick FN, Hockett ME, Saxton AM, Lewis MJ, Dowlen $\mathrm{HH}$ Oliver SP. Influence of subclinical mastits during early lactation on reproductive parameters. J Dairy Sci 2001;84:1407-12.

[42] Santos JE, Cerri RL, Ballou MA, Higginbotham GE, Kirk JH. Effect of timing of first clinical mastitis occurrence on lactational and reproductive performance of Holstein dairy cows. Anim Reprod Sci 2004;80:32-45.

[43] Thompson JR. Genetic interrelationships of parturition problems and production. J Dairy Sci 1984;67:628-35.

[44] Azawi OI. Postpartum uterine infection in cattle. Anim Reprod Sci 2008;105:187-208.

[45] Schukken YH, Nollis N, Erb R, Smith D. The relationship between mastitis and retained placenta in a commercial population of Holstein dairy cows. Preventative Vet Med 1998:5:181-90.

[46] Berry DP, Kearney JF, Twomey K, Evans RD. Genetics of reproductive performance in seasonal calving dairy cattle production systems, Irish J Agric Food Res 2013;52:1-16.

[47] Echternkamp SE, Gregory KE. Effects of twinning on gestation length, retained placenta and dystocia. J Anim Sci 1999;77:39-47.

[48] Gregory KE, Echternkamp SE, Dickerson GE, Cundiff LV, Koch RM, van Vleck LD. Twinning in cattle III. Effects of twinning on dystocia, reproductive traits, calf survival, calf growth and cow productivity. J Anim Sci 1990;68:3133-44.

[49] Gaverick HA. Ovarian follicular cysts in dairy cows. J Dairy Sci 1997; 80:995-1004.

[50] Kim KD, Ki KS, Kang HG, Kim IH. Risk factors and the economic impact of ovarian cysts on reproductive performance in dairy cows in Korea. J Reprod Dev 2005;51:491-8.

[51] Sheldon IM, Lewis GS, LeBlanc S, Gilbert RO. Defining postpartum uterine disease in cattle. Theriogenology 2006;65:1516-30.

[52] Sandals WC, Curtis RA, Cote JF, Martin SW. The effect of retained placenta and metritis complex on reproductive performance in dairy cattle: a case control study. Can Vet J 1979;20:131-5.

[53] Gilbert RO, Shin ST, Guard CL, Erb HN, Frajblat M. Prevalence of endometritis and its effects on reproductive performance of dairy cows. Theriogenology 2005;64:1879-88. 